\title{
Lord Byron, Leigh Hunt and THE LIBERAL: Some New Evidence
}

\author{
O. M. B RA C K, J R .
}

On October 15, 1822, after many difficulties, the first number of The Liberal was published by John Hunt in London. ${ }^{1}$ Many of the difficulties centered around Byron's publisher, John Murray, because of his reluctance to turn over manuscripts in his possession to John Hunt as Byron directed and because of his indiscretion in repeating to various persons strictures on the character of Leigh Hunt by Byron which were intended for him alone. In an unpublished letter ${ }^{2}$ recently acquired by the University of Iowa Library for the Brewer-Leigh Hunt Collection, Byron candidly writes to Mary Shelley concerning these difficulties:

[Octo]bre 14th 1822

Dear M.-

The letter is all very well-but I wish that he would press upon his brother $^{3}$ (what is of more importance at least to the quantity of the publication) the expediency of seeing Mr K.4 the moment he is well enough to receive visitors-else he may never get the M. S. S. at all from Murray-who seems to stick at nothing in all that relates to Hunt's family. As to any expression in private letters about Hunt or others-I am not a cautious letter-writer and generally say what seems apparent at the moment, but I remember in my more deliberate memoirs (which Murray bought of Moore) having done his character justice-why didn't

1 For a full discussion of the problems surrounding the publication of the first number of The Liberal see William H. Marshall, Byron, Shelley, Hunt and 'The Liberal (Philadelphia: University of Pennsylvania Press, 1960), 50-134. Also Leslie A. Marchand, "John Hunt as Byron's Publisher," Keats-Shelley Journal, VIII (1959), 119-132.

2 Here published by permission of Sir John Murray and not to be further reproduced without his authorization.

3 Byron is urging Mary Shelley to have Leigh Hunt press upon his brother, John.

${ }^{4}$ Douglas Kinnaird (1788-1830) acted as Byron's business manager and literary agent. He had been thrown from his horse. The Works of Lord Byron: Letters and Journals. ed. Rowland E. Prothero (London, 1898-1901), VI (1901), 149. 
M. allude to them?-it were less a breach of confidence than the other?The whole thing has been a piece of officious Malice on the part of M. \& not very discreet zeal on the part of Hunt's friends.-

\section{Yrs. ever}

N. B.

P.S.

I send you the completion of the first part-of the dramaas I think it may be as well to divide it.- although intended to be irregular in all its branches. ${ }^{5}$

Byron Oct. 14th, 1822

This letter raises the problem as to which letter, or possibly letters, contained the strictures of Byron on Hunt's character. Marshall assumes that the letter containing the strictures circulated by Murray was one dated October $9,1822^{6}$ in which Byron states:

I am afraid the Journal is a bad business, and won't do; but in it I am sacrificing myself for others-I can have no advantage in it. I believe the brothers $H$. to be honest men; I am sure that they are poor ones. . . . I have done all I can for Leigh Hunt since he came here; but it is almost useless: his wife is ill, his six children not very tractable, and in the affairs of this world he himself is a child. ${ }^{7}$

It is impossible, however, that Byron could have mailed a letter from Genoa dated October 9, Murray have circulated it, John and Henry Hunt have heard rumors of it, and then by October 14 have discussed with Mary Shelley the furor the letter had already caused. Marshall quotes Theodore Hook's account of the letter in John Bull: "Hunt is a bore, he is,' says his Lordship, 'a proser; Mrs. Hunt is no great things; and their six children perfectly intractable." "8 Marshall further assumes that this is "a garbled account of the contents of Byron's letter." There is evidence, however, which indicates that Hook's account is not as garbled as it might seem. In a letter to Murray dated October 25 Byron states:

My original motives I already explained (in the letter which you thought proper to show): they are the true ones, and I abide by them, as I tell you, and I told Lh. Ht. when he questioned me on the subject of that letter. He was violently hurt, and never wil forgive me at bottom; but I can't help that. I never meant to make a parade of it; but if he chose to question

5 Byron sent part of his poetic drama, The Deformed Transformed, for Mary Shelley to copy. The Letters of Mary W. Shelley. ed. Frederick L. Jones (Norman: University of Oklahoma Press, 1944), I, 199.

6 Marshall, pp. 91-92.

7 Letters and Journals, VI, 122-125.

8 John Bull, No. 98 (October 27, 1833), p. 781.

${ }^{9}$ Marshall, p. 91. 
me, I could only answer the plain truth: and I confess I did not see anything in the letter to hurt him, unless I said he was "a bore," which I don't remember. ${ }^{10}$

Then in a letter dated November 11, Hunt told Byron:

My 'wife and six small' come rather hard upon me in the business,-but a little reflection takes the heat out of my cheeks: and as to your 'proser,' God knows I should never think it worth a savager answer than to lay hold of one of my puns, and say you're a 'worser.'11

Although the letter dated October 9 mentions that intractability of the six children, it mentions nothing about Hunt's being "a bore" or "a proser." Hunt mentions the epithet "proser" and it is possible that by November 11 he could have heard about the October 27 account of the letter in John Bull. But Byron, in a letter written two days before the John Bull account appeared, indistinctly remembers calling Hunt "a bore." This piece of evidence, along with the knowledge that it generally took two weeks for a letter to reach London from Italy, makes it possible to surmise that there is, or was, a letter, or possibly letters, written about the middle of September, or earlier, which calls Hunt "a bore" and "a proser," and which makes disparaging remarks about Mrs. Hunt and the six children.

10 Letters and Journals, VI, 156-157.

11 Brewer Collection MsL/H94by. Published in Luther A. Brewer, My Leigh Hunt Library: Holograph Letters (Iowa City: University of Iowa Press, 1938), p. 122. 